Egypt . J. Anim. Prod. , Vol. 28,No. 1, pp., 31 - 38 (1991).

\title{
Seasonal Variation in The Fertility of Crossbred Ewes
}

\author{
M.M. Mokhtar, H.T. Aldel Bary", A.M. Li - Sharabasi" \\ and A.K. Hammam \\ Department of Animal Production, Desert Institute, Mataria \\ and Department of Animal Production*, Faculty of \\ Agriculture, Al - Azhar Universiry, Cairo, Egypt.
}

\begin{abstract}
C EVERTY one sdult crossbred Merino and Barki ewes of mixed $S$ ages were used in this experiment to examine seasonal variation not related to nutritional differences in ovulation, conception and embryonic survival rates. Ewes were divided at random within age into 3 groups, one was joined with fertile rams in October while the second and third were joinet with the same rams during Februsry and June, respertively. Oestrus was observed and rocorded daily. Feeding regime was standerised for all experimental groups. Almost half the number of ewes in each season were slaughtered on the 3rd day after mating while the rest were slaughtered at 34 th day post ccitum. The presence of corpus luteum was taken as an indication for ovulation. Ewes matai in October scord the highest orulation rate (137.5\%) followed by those mated in February (104.3\%) and then by June mated ones (100.04\%). Embryonic survival rate ranged from 76.5 to $88.9 \%$ among diffexest sessons, with differenoes being not significant. Considering both ovulation and enbryonic survival rates observed in the present stady October season ranks the first, followed by Jone and February in descending order. Such differences however, were not siguifickant.

Seasonal variation in ewes fertility are not related to nutritional differences and inay be due to changes in clinatic conditions, possibiy photoperiod and / or arnbient temperature.

It is conchuded that treeding in different seasons is possible providing that optinum managenent of feoding is insured.

Keywords : Mermo Barki Crossbred, Season, Ovulation rate and embryonic survival rate.
\end{abstract}

Rebreedng is considered one of the must practical and efficient methods to insensify lamb proubction in continuous breeders under local conditions. This is because locsl ewes exhibit oestrus all year around (E1 - Fouly et al ., 1977, Younis, 1977 and Aboul Naga and Áboul - Ela, 1985). 
A systern of 3 lambings per 2 years was suggested by Younis (1977) and put in practice on a large scale by Aboul - Naga (1983) and Mokhtar et al ., (1991). To obtain 3 lambings per 2 years the months of February, June and October were selected for breeding (Mokhtar et al ., 1991). Thouigh total productivity increases as a result of applying such system, seasonal differences in fertility wene observed. Aboul - Naga (1983) found that there was a significant variation in the breeding activity at different mating seasons. Previous work in this laboratory (Mokhtar et al ., 1991) showed that ewes mated in October had a higher conception rate compared to those mated in either June or February. Reasons behind such differences are not yet fully understood or investigated. However, these differences may be due to muiritional and / or other climatic factors. This paper examines seasonal variation not related to nutritional differences in certain physiological parameters, mainly ovulation and embryonic survival rates.

\section{Materiais and Methods}

\section{Experimental animals.}

Seventy one adult crossbred Merino and Barki ewes of mixed ages with an average livebody weight of $52.1 \mathrm{~kg}$ were used in this experiment. These ewes were part of the main flock raised at Maryout Experimental Station which belongs to the Desert Institute, Located some $35 \mathrm{~km}$ south west of Alexandria.

\section{Treasments}

Before starting the experiment ewes were divided at random within age into 3 groups, the first one comprised 24 ewes. During October these ewes were joined with 2 fertile rams in a separate mating pen for 34 diays, while the second one ( 23 ewes) was joined with the same two rams for the same length of mating period during February. The same procedure was adopted with the third group ( 24 ewes) during June.

During maling periods rams were colour painted on their briskets every day and oestrus was observed and recorded daily for each individual ewe throughout the 34 day mating period in October, February and June.

Feeding regime was standerised for all experimentai groups according to their average livebody weight to avoid any tutritional - climatic confounding effect on their ferility. Animals were fed in each treatment group on a dict which consisted of a concentrate mixture (cottonseed cake $50 \%$, wheat bran $18 \%$, yellow maize $15 \%$ rice polish $11 \%$, molasses $3 \%$, Limestone $2 \%$ and common salt $1 \%$ ) at the rate of $1 / 2 \mathrm{~kg} /$ head / day plus $1 / 2 \mathrm{~kg} /$ head / day Berseem (Trifolium alexandrinum) hay. Fresh water was available twice daily for all experimental groups.

\section{Observations recorded \\ Slaughter date}

One of the main objectives of the present study was to investinate the effect of sea-

Egypt. J. Anims. Prod., 28, No. 1 (1991) 
son of breeding on ovulation and embryonic survival rates. Therefore almost half the number of ewes in each season were slaughtered, on the 3rd day after mating. Soon after slaughter each genitalia was removed and both ovaries were examined for the presence of Corpora lutea. The presence of corpus luteum was taken as an indication for ovulation. The rest of the ewes, from each treatment group were also slaughtered on the 34th day after mating. Soon after slaughter each genitalia was removed and examined for $\mathrm{em}-$ bryo survival.

Weights of the whole genitalia as well as the weight of each separate part was obtained and recorded to the nearest gram.

\section{Statistical analysis}

Chi - square test was performed for ovulation, conception and embryonic survival rates to detect differences among different scasons. However, an analysis of Covariance was carried out for all weights of genitalia as to remove any effect due to changes in livebouly weight of animals just before slaughter (Snedecor and Cochran, 1970).

\section{Results and Discussion}

\section{Orulation and conception rates}

Ewes mated in October and slaughtered on 3rd day post coitum scord the lighest ovulation rate (123.1\%) followed by those mated in February (115.4\%) and then by June mated ones (100.0\%) (Table, 1). Ewes slanghtered on 34th day post coitum showed almost the same pattern for ovulation rats with values of $154.5,90.0$ and $100 \%$ for October, February and June, respectively. Thus, the overall ovulation rate for ewes slawghtered on both occasions was found to be $137.5,104.3$ and 100.0 for October, February and June, respectively, with differences being not significant. These results may explain the high twinning rate observed for local ewes bred in September - October period reported by previous aushors (Aboul Naga and Aboul - Ela, 1985) which is a direct result to the high ovulation rate occurs during such pariod. It is of significance as well to note that ewes bred in the conventional breeding serison of June to have a low ovulation rate and consequently will be expected to give a low twinning rate. However, part of the differences among seasons in ovulation rate may be due to differences in livebody weight of ewes. In the present study October mated ewes were, on the average, higher than June mated ones in their body weight by almost $10 \mathrm{~kg}$ (Table 1). Edey (1968) investigated the relationship between body weight at the time of ovulation and ovulation rate in mature Merino ewes, and found that body weight below $35.0-37.5 \mathrm{~kg}$ was associated with an ovulation rate of approximately, $105 \%$ and varied a little with body weight above this level. For each increase of $2.5 \mathrm{~kg}$ in body weight there was at least a $5 \%$ increase in ovulation rate up to $53.5 \mathrm{~kg}$, and at least a $10 \%$ increase per $2.5 \mathrm{~kg}$ within the range of 40.4 $-48.0 \mathrm{~kg}$. 


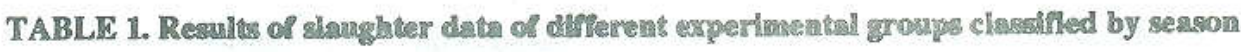

\begin{tabular}{|c|c|c|c|}
\hline \multirow[b]{2}{*}{ Triat } & \multicolumn{3}{|c|}{ Sesson } \\
\hline & Ostober & February & June \\
\hline Total number of ewes & 24.0 & 23.0 & 24.0 \\
\hline Average livebody weight ( $\mathrm{kg}$ ) & 56.4 & 53.7 & 46.2 \\
\hline No. of ewes slaughtered on 3rd day Post - Coitum & 13.0 & 13.0 & 11.0 \\
\hline No. of ewes with corpora lutea & 12.0 & 13.0 & 10.0 \\
\hline No. of corpora luten (C.L. & 16.0 & 15.0 & 11.0 \\
\hline $\begin{array}{l}\text { Ovulation rate for ewes slarghtered on 3rd day } \\
\text { post coitum (\%) }\end{array}$ & 123.1 & 115.4 & 100.0 \\
\hline No. of ewes slaughtered on 34th day post - coitum & 11.0 & 10.0 & 13.0 \\
\hline No. of ewes with corpora lutes & 11.0 & 7.0 & 13.0 \\
\hline Conception rate & 100.0 & 70.0 & $100.0^{*}$ \\
\hline $\begin{array}{l}\text { No. of corpora lute } \\
\text { ovulation rate for ewes slaughured on } 34 \text { th disy }\end{array}$ & 17.0 & 9.0 & 13.0 \\
\hline $\begin{array}{l}\text { ovulation rate for ewes slaughtured on } 3 \text { oth disy } \\
\text { post coitum }\end{array}$ & 154.5 & 90.0 & 100.0 \\
\hline Overall ovulation rate for all awes & 137.5 & 104.3 & 100.0 \\
\hline No. of ewes with embryos & 9.0 & 6.0 & 11.0 \\
\hline No. of viable embryos & 13.0 & 8.0 & 11.0 \\
\hline$\%$ of survived embryos & 76.5 & 88.9 & 84.6 \\
\hline Expected lambings rate & 118.2 & $\$ 0,0$ & - \\
\hline
\end{tabular}

Ovaluation rate $=\frac{\text { No. of corpora hatee }}{\text { No. of ewer shaghluered }} \times 100$

\% of survived embryos $=\frac{\text { No. of viuble embryos }}{\text { No. of corpora hutes }} \times 100$

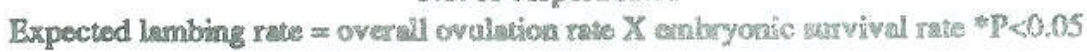

Coop (1966), reported that twinuing wias increased by $6 \%$ for each $10.1 \mathrm{bs}(4.5 \mathrm{~kg})$ increase in liveweight at masing. Conception rate was found to be inferior $(70 \%)$ for ewes mated in February than their cownteparts mated in eicher October or June (100\%), differences being significaget $\left(x^{2}=6.5\right)$.

\section{Eonbryonic survival rets}

Embryonic survival rate ranged from 76.5 to $88.9 \%$ among different seasons (Table 1), diffenences, however, wene significant $\left(x^{2}=0.72\right)$. Enabryoulc stirvival rate had almost an inverse relationshiry, with ovulation rate (Table 1). Ewes bred in October, though had the bighest ovalation rate, they showed the lowest embryonic survival rate. This low embryonic survival rase for October baed group makked a part of its superionity in ovelation rate. The relstionshig between ovalakion rate and embryonic survival nate were investigated by different authors (Gdey. 1960 ) and there is almost ss gereval agree-

Egypr. J. Anim. Prod, 2a, No. 1 (1991) 
ment that embryonic rontality rate increase with the increase in the ovulation rate. This may be a mechanism by which adapted animals keep it's equalibrium under a certain set of environment.

Results of the present study indicate that differences among seasons in feriility are mainly due to differerces in ovulation, conception and embryonic survival rates. Such differences in ovulation, conception and embryonic survival rates ane not related to any nutritional differences since feeding regime was standerized for animals bred in ail seasons. Accordingly these differences reflects mereiy seasonal diffierences possibly due to changes in photoperiod and / or ambient temperature. Mokhtar et al . (1991) found that ewes mated in October had a higher conception rate compared to those mated in either June or February. Aboul - Naga et al . (1991) found as well that there was a significant variation in the breeding activity of ewes at different mating seasons.

Considering both ovulation and embryonic survival rates observed in the present study October season ranks the first in the expected lambing rate, followed by June and February in a descending order. These resuits supported finding of previous authors (Aboul - Naga et al ., 1991 and Mokhtar et al ., 1991) in that September - October breeting season is considered the best in the overail fertility of ewes under local conditions.

\section{Gentaiia}

As previously mentioned genitalia of ewes slatghtered on both 3rd and 34 th days post coitum were examined. Weight of genitalia ranged from 128.3 in June to $193.8 \mathrm{~g}$ in October at three days post Coitum, differences being significant $(P<0.05)$. Corresponding values on 34 th day post coitam were 272.3 and $304.5 \mathrm{~g}$ with no significant difference. These differences may indicate the presence of more active genitalia in October season since the effect of livebody weight on the weight of genitalia was removed by analysis of covariance.

Weight of right ovary was found to be 1.1, 1.2 and $1.2 \mathrm{~g}$ on the third day post coitum for June, Ociober and February bred ewes with corresponding values of $1.3,1.3$ and 1.2 $\mathrm{g}$ for left ovary, differences were not significant. However, on 34 th days Post Coitum October bred ewes had significantiy higher values for right ovaries $(1.9 \mathrm{~g})$ compared to either June $(1.7 \mathrm{~g})$ or February $(1.3 \mathrm{~g})$ bred ewes. Weight of left ovaries on 34 th day Post Coitum did not differ significanly amcng seasons being $1.0,1.5$ and $1.8 \mathrm{~g}$ for June October and February bred ewes.

Apart from that no significant differences were observed due to season among different parts of genitalia on the 3ruday Post Coitum. However, on 34th Post Coitum October bred ewes significantly $(P<0.01)$ exceeded their counterparts in the weight of oviduct being $0.8,1.3$ and $1.1 \mathrm{~g}$ for June October and February bred ewes. On the other hand February bred ewes exceeded significantly $(\mathbb{P}<0.05)$ their counterparts in the width of left ovary being $1.3,1.2$ and $1.4 \mathrm{~cm}$ for June, October and February bred ewes, respectively. Similarly Febnary bred ewes had significantly $(P<0.05)$ bigher values for 
the volume of the left ovary being $1.0,1.5$ and $1.6 \mathrm{~cm}^{3}$ for June, October and February bred ewes.

February bred ewes exceedlod June and October ones in nost embryonic traits (Table 2), though differences were not significant.

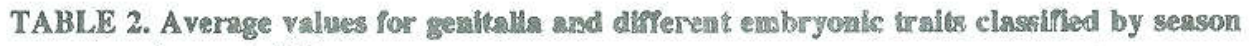
(mean $\pm \mathrm{SE}$ )

\begin{tabular}{|c|c|c|c|}
\hline \multirow[b]{2}{*}{ Item } & \multicolumn{3}{|c|}{ Season } \\
\hline & Detolier & Febras:y & June \\
\hline \multicolumn{4}{|l|}{ Weight of genitalia (g) } \\
\hline on 3rd day post - coitum & $193.8 \pm 7.38$ & $136.1 \pm 8.04$ & $128.3 \pm 7.39 *$ \\
\hline on 34 th day post coitum & $3045 \pm 29.68$ & $289.6 \pm 58.49$ & $272.3 \pm 17.82$ \\
\hline \multicolumn{4}{|l|}{ Weight of rightovary (g) } \\
\hline on 3rd day post - coitumi & $1.2 \pm 0.12$ & $1.2 \pm 0.05$ & $1.1 \pm 0.12$ \\
\hline on 34th day post coitum & $1.9 \pm 0.21$ & $1.3 \pm 0.15$ & $1.7 \pm 0.16^{*}$ \\
\hline \multicolumn{4}{|l|}{ Weight of left cvary (g) } \\
\hline on 3rd day post - soitum & $1.3 \pm 0.12$ & $1.2 \pm 0.065$ & $1.3 \pm 1.70$ \\
\hline on 34th day post coitum & $1.5 \star 0.15$ & $1.8 \pm 0.27$ & $1.0 \pm 0.0 \% * *$ \\
\hline \multicolumn{4}{|l|}{ Weight of oviduct (g) } \\
\hline on 3rd day post - coitum & $1.3 \pm 0.13$ & $1.2 \pm 0.07$ & $1.1 \pm 0.05$ \\
\hline on 34th day post coirum & $1.3 \pm 0.12$ & 1.110 .07 & $0.8 \pm 0.07 * *$ \\
\hline \multicolumn{4}{|l|}{ Width of left ovary (cm) } \\
\hline on 3rd day post - coitum & $1.3 \pm 0.06$ & $1.4 \pm 0.10$ & $1.3 \pm 0.06$ \\
\hline on 34th day post coitum & $1.2 \pm 0.07$ & $1.4 \pm 0.10$ & $1.3 \pm 0.05$ \\
\hline \multicolumn{4}{|l|}{ Volum of left ovary $\left(\mathrm{cm}^{3}\right)$} \\
\hline on 3rd day post - coitum & $1.1 \pm 0.12$ & $1.6 \pm 0.22$ & $1.1 \pm 0.14$ \\
\hline on 34th day post coitum & $1.3 \pm 0.17$ & $1.6 \pm 0.22$ & $1.0 \pm 0.06^{*}$ \\
\hline Weight of chorionic vesicle $(g)$ & $81.2 \pm 12.6$ & $119.5 \pm 38.66$ & $93.5 \pm 0.86$ \\
\hline Weight of amniotic sac + embryo (B) & $10.0 \pm 0.89$ & $15.5 \pm 1.97$ & $11.5 \pm 1.96$ \\
\hline Weight of amnion (g) & $6.3 \pm 0.87$ & $11.7 \pm 1.88$ & $8.8 \pm 1.72$ \\
\hline Weight of embryo (g) & $1.9 \pm 0.12$ & $2.7 \simeq 0.19$ & $1.8 \pm 0.22$ \\
\hline Crown rump length $\mathrm{CRL}(\mathrm{cm})$ & $2.6 \pm 0.08$ & $2.8 \pm 0.13$ & $2.7 \pm 0.14$ \\
\hline No. of Cotyledons in right hom & $29.8 \pm 3.05$ & $37.3 \pm 2.11$ & $46.5 \pm 3.27$ \\
\hline No. of Cotyledons in left hom & $28.1 \pm 4.03$ & $38.3 \pm 3.42$ & $42.0 \pm 2.92$ \\
\hline
\end{tabular}

* $\mathrm{P}<0.05 \% \mathbb{P}<0.01$

Egypt. J.Anim. Prod., 28, No. 1 (1991) 
In conclusion, Seasonal varistion in ewes fertility are not related to nutritional differences and may be due to changes in climatic conditions, Possibily photoperiod and / or ambient temperature. So, breeding in different seasons is possible providing that optimum management of feoding is insured.

\section{References}

Aboul - Nggh, A.M. (1983) Lamb crop every eight months from subtropical fat - tailed sheep. The Vth world Conference on Aninal Production, August 14 - 19. Japinese Society of Zootocknical Science, Takyo, Japar, Vol $2: 147$.

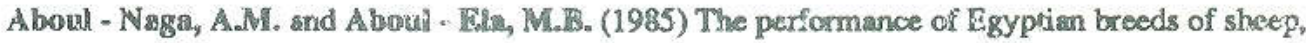
European breeds and their corsese. 1. Egyptian sheep breeds. 36 in Annual Meeting of The European Association For Animal Production, Kaltishce, Halliciki, Greece, Sept. 30 - Octo. 3, 1985.

Aboul - Nagsw, A.M., Alboul - Ela, M.B. , Massonar, kl. and Almahdy, H. (1991) Breeding activity of two subtropical Egyptian sheep breads under anceier strad lambing system. Small Rumimaxs Research 4:285.

Cocp, I.E. (1966) Effect of flushing on reproductive performance of ewes. J. Agric. Sci. Cumb., 67 $: 305$.

Edey, T.N. (1966) Nutritional stress and preimplantation embryonic nortality in Merino sheep. $J$. Agric. Sci. Camb., $67: 287$.

Edey, T.N. (1968) Bodyweight and ovnlation yed in shoep. Arime, Breed. Abet., $37: 456$.

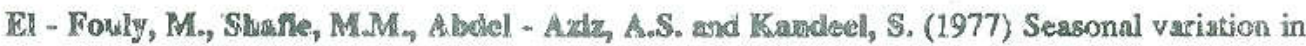
cestrous activity in Ossinni and Kithunati ewes. Egypt. J. Anim. Psad., 17 : 75.

Moldhtar, M.M. Aludel Bard, H.T. ,Youmde, A.A.y Mabroula, M.S. and Abdel Azdz, H. (1991) Comparative study of two systems of production in Barki sheep. Egypt. J. Anim. Prod. 28 : 21.

Snedecor,G.W. and Cochram, W.G. (1970) Statisticial Meshods. 5th ed. Iows State University, Ames, Iowa.

Younis, A.A. (1977) Increasing ewe fertility in Arab countries. World. Review of Anim. Prod., 13 : 361. 


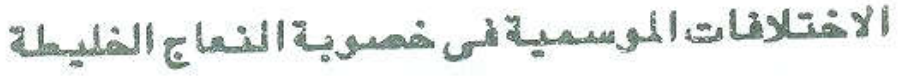

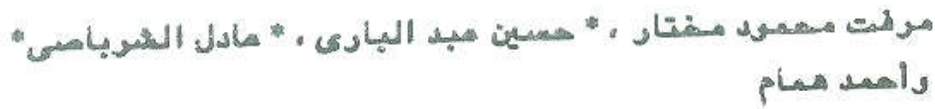

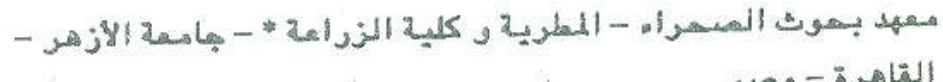

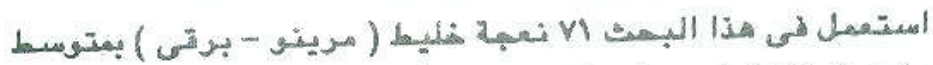

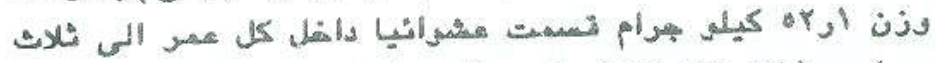

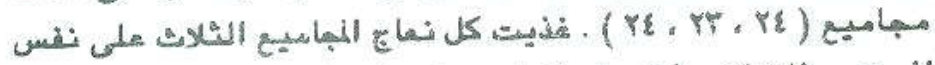

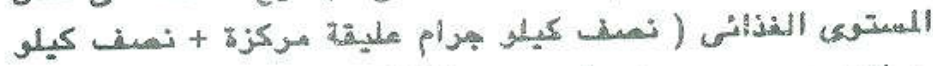

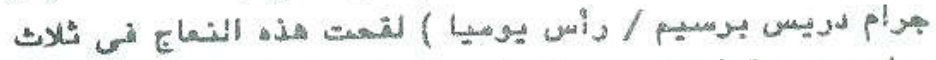

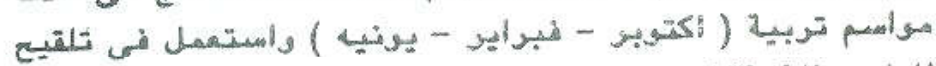

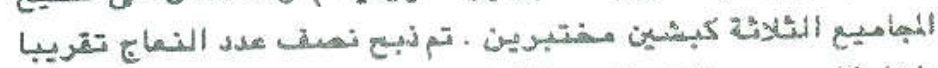

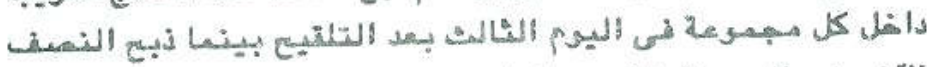

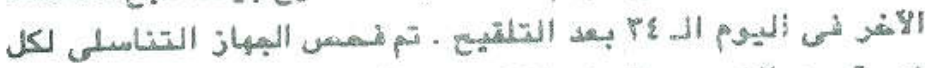

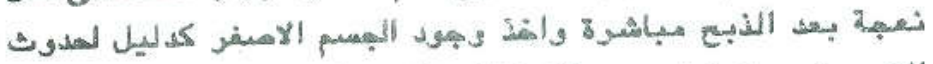

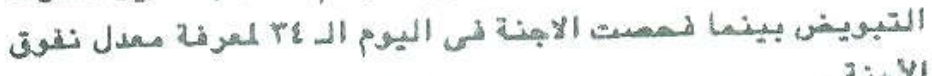

$$
\text { - } 11
$$

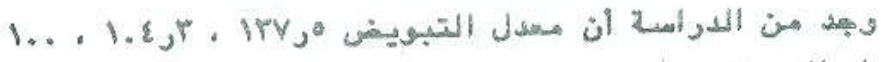

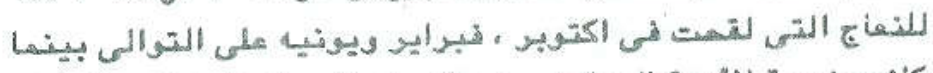

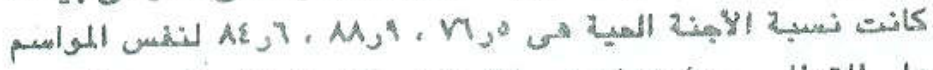

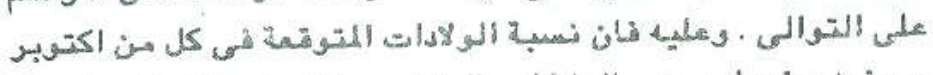

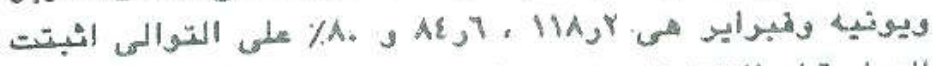

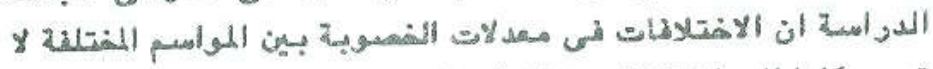

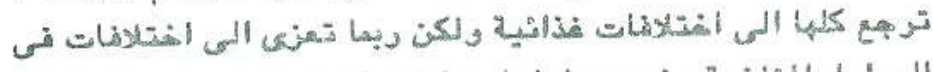

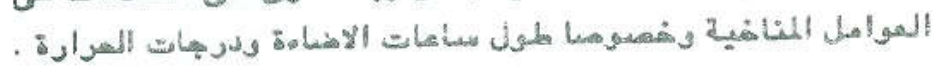

